\title{
Management optimization of dual-purpose barley (Hordeum spontaneum C. Koch) for forage and seed yield
}

\author{
MOH'D KHAIR J. EL-SHATNAWI, LOUY Z. AL-QURRAN, AND KHALIL I. EREIFEJ AND HANI M. SAOUB
}

Authors are Associate Professor of range ecology, Natural Resources Department, Faculty of Agriculture, Jordan University of Science and Technology, PO Box 3030, Irbid 22110, JORDAN, E-mail:mkhair@just.edu.jo, National Center for Agricultural Research and Technology Transfer, Amman, JORDAN, and Professor of food technology, Faculty of Agriculture, Jordan University of Science and Technology, PO Box 3030, Irbid 22110, JORDAN, and Assistant Professor of Agronomy Faculty of Agriculture, University of Jordan, Amman 11942, Jordan.

\section{Abstract}

Dual-purpose barley (Hordeum spontaneum C. Koch.) is a winter annual native to Southern Mediterranean regions. It is used to establish permanent pasture because it has a brittle rachis. Crude protein, crude fiber contents, and responses of dual-purpose barley to time of defoliation were investigated in the northern mountains of Jordan. Field trials were conducted in the 1999-2000 and 2000-2001 growing seasons in Samta $\left(32^{\circ} 23^{\prime} \mathrm{N}\right.$, $\left.35^{\circ} 50^{\prime} \mathrm{E}\right)$ at an elevation of $1043 \mathrm{~m}$. The highest protein contents $(P \leq \mathbf{0 . 0 5})$ of $25 \%$ were recorded in February 2001. Protein content declined gradually and reached the lowest values $(2.5 \%)$ at maturity. Clipping produced shorter plants, but did not impact tillering.

Clipping individual plants on 28 February (14.3 and $10.2 \mathrm{~g}$ plant $^{-1}$, respectively in 2000 and 2001) and 15 March (10.3 and 9.2 g plant ${ }^{-1}$, respectively in 2000 and 2001) did not reduce the plant shoot weight. Forage production from plants clipped on 28 February (2902 and $1274 \mathrm{~kg} \mathrm{ha}^{-1}$, respective years), 15 March (1793 and $1394 \mathrm{~kg} \mathrm{ha}^{-1}$, respectively in 2000 and 2001) and 15 April (1554 and $994 \mathrm{~kg} \mathrm{~h}^{-1}$, respectively in 2000 and 2001) were similar to forage production from unclipped plants. Clipping on 15 April inhibited seed production. Defoliation during early growth stages optimized seed yield and forage quantity and quality.

Key Words: Defoliation time, Jordan, protein, spontaneum, tiller

Dual-purpose barley (Hordeum spontaneum C. Koch.) grows in areas with a Mediterranean climate. It is well adapted to dispersal by animals and humans. Dual-purpose barley has a brittle rachis; therefore, it was used to establish permanent pasture in marginal lands, stony fields, and hilly areas in which agricultural equipment for sowing is not available each year. In Jordan, many Hordeum species can be grazed at the tillering stage without a reduction in forage and grain production of individuals or the population (Anderson 1985, El-Shatnawi and Gosheh 1998, ElShatnawi et al. 1999). Growth stage significantly affects the protein content of grasses where the crude protein content decreases with advancing maturity. Most forage grasses usually contain high nutritive value during early growth, but their forage value

The study was financially supported by Jordan University of Science and Technology and the Agrobiodiversity project at National Center for Agricultural Research and Technology Transfer. We would like to thank Dr. Rex Pieper for his valuable editorial comments and suggestions.

Manuscript accepted 14 Jun. 04.

\section{Resumen}

La cebada de doble propósito (Hordeum spontaneum C. Koch.) es una especie anual invernal nativa de las regiones sureñas del Mediterráneo. Es utilizada para establecer praderas permanentes porque tiene un raquis quebradizo. En las montañas del norte de Jordan se investigó el contenido de proteína y fibra cruda y la respuesta de la cebada de doble propósito a la época de defoliación. Los estudios de campo se realizaron en las estaciones de crecimiento de 1999-2000 y 2000-2001 en Samta (32 ${ }^{\circ}$ $23^{\prime} \mathrm{N}, 35^{\circ} 50^{\prime} \mathrm{E}$ ) a una elevación de $1043 \mathrm{~m}$. Los contenidos más altos de proteína $(P \leq \mathbf{0 . 0 5}), 25 \%$, se registraron en Febrero de 2001. El contenido de proteína disminuyó gradualmente y alcanzó su contenido más bajo en la madurez $(2.5 \%)$. El corte produjo plantas más cortas, pero no tuvo impacto en el ahijamiento. El corte de plantas individuales en el 28 de Febrero (14.3 y 10.2 g planta $^{-1}$, respectivamente en 2000 y 2001) y el 15 de Marzo (10.3 y 9.2 g planta $^{-1}$, respectivamente en 2000 y 2001) no redujo el peso de los tallos de la planta. La producción de forraje de las plantas cortadas el 28 de Febrero $\left(2902\right.$ y $1274 \mathrm{~kg} \mathrm{ha}^{-1}$ en 2000 y 2001 respectivamente), el 15 de Marzo (1793 y $1394 \mathrm{~kg} \mathrm{ha}^{-1}$ en 2000 y 2001 respectivamente) y el 15 de Abril (1554 y $994 \mathrm{~kg} \mathrm{ha}^{-1}$ en 2000 y 2001 respectivamente) fueron similares a la producción de forraje de las plantas sin corte. Cortar en el $\mathbf{1 5}$ de abril inhibió la producción de semilla. La defoliación durante las etapas tempranas de crecimiento optimizaron la producción de semilla y la calidad y cantidad de forraje.

declines rapidly at maturity (Kalmbacher 1981a, 1981b, Cherney and Marten 1982, Stidham et al. 1982, Louis et al. 1983). The crude protein content of barley shoots was as high as $20-30 \%$ at the tillering stage (Anderson 1985, Droushiotis and Wilman 1987).

Management of dual-purpose barley for both forage and seed production would improve the diversity options for livestock producers. Many cool-season grasses can be managed for both forage and seed from the same stand (Kroth et al. 1977). Understanding plant responses to defoliation allows farm managers to choose the proper timings for plant use and rest, which permits better management of range plant communities (Jameson and Huss 1959). Plant response to green material removal varies greatly with season. Defoliation time affects range grass development (Miller and Donart 1979, Mullahey et al. 1990), where the most critical period is during the reproductive stage. As the reproductive stage is approached, the plants become more sensitive to defoliation (Tarassoum 1982, Moser and Perry 1983). Barley 
grazed at the pre-stem elongation stage allows recovery and production of grain yield equivalent to that of ungrazed stands (Morey 1961); therefore, dual-purpose barley is becoming more popular in Iraq because it tolerates grazing at the pre-stem elongation stage (AL-Rawi et al. 1995). Prior knowledge of the defoliation effects on plants is thus crucial for successful pasture management. The objective of this study was to investigate the effect of defoliation time on growth and production of dual-purpose barley under Ajloun Mountain conditions.

\section{Materials and Methods}

\section{Site description}

A field trial was conducted during the 1999-2000 and 2000-2001 growing seasons at Samta $\left(32^{\circ} 23^{\prime}, 35^{\circ} 50^{\prime} \mathrm{E}\right)$ in the Ajloun Mountains, Jordan at $1043 \mathrm{~m}$ above sea level. The soil is a moderate to deep brown loamy clay classified as Typic Haploxerets (Bsoul 2002). The highest dry matter accumulation and the most rapid plant growth occur between January and March and cease by May. The climate has a Mediterranean pattern with cold-humid winters and hot-dry summers. Precipitation distribution also has a Mediterranean pattern with an annual long-term average of $600 \mathrm{~mm}$ (Fig. 1). Generally, rainfall starts during late October and ends during early May with maximum occurring during January and February. Average temperatures range from $9.5 \mathrm{C}^{\circ}$ in January to 22.1 $\mathrm{C}^{\circ}$ in May.

\section{Seedbed preparation}

The seeds of dual-purpose barley were collected during summer 1999 from the Ajloun Mountains. The soil was chisel plowed in September and November of each year. Seeds were broadcast in $25-\mathrm{cm}$ spaced 6-m rows at a seeding rate of $60 \mathrm{~kg}$ $\mathrm{ha}^{-1}$. Defoliation treatments of clipping the plants on 28 February, 15 March, 30 March, 15 April of 2000 and 2001 and the control (clipping the plant when it reached seed maturity) were randomly assigned to the plots (6 rows) and replicated 4 times. The regrowth from plots that was clipped 28 February, 15 March, 30 March or 15 April 2000 and 2001 was reclipped at seed maturity. The control plots were only clipped at seed maturity.

The effect of defoliation time on dualpurpose barley was determined by measuring plant height $(\mathrm{cm})$, number of tillers per plant, plant shoot weights ( $\mathrm{g}$ plant $^{-1}$ ), dried forage weights $\left(\mathrm{kg} \mathrm{ha}^{-1}\right)$, and seed weight $\left(\mathrm{g}\right.$ plant $\left.{ }^{-1}\right)$ when plants reached maturity. Data were recorded on the 4 central rows of each plot. Total oven dry forage weight was determined by adding the weight of tops removed at time of defoliation to the forage weight obtained when harvesting the plant at seed maturity. Plants were clipped up to $5-\mathrm{cm}$ above the soil surface. Oven-dry forage weight (vegetative shoot weight) was determined by drying shoots at $80^{\circ} \mathrm{C}$ for 72 hours. Data recorded on the individual plant (seed yield per plant, number of tillers per plant, and oven dry forage weight per plant) were the average of 5 randomly selected plants per plot.

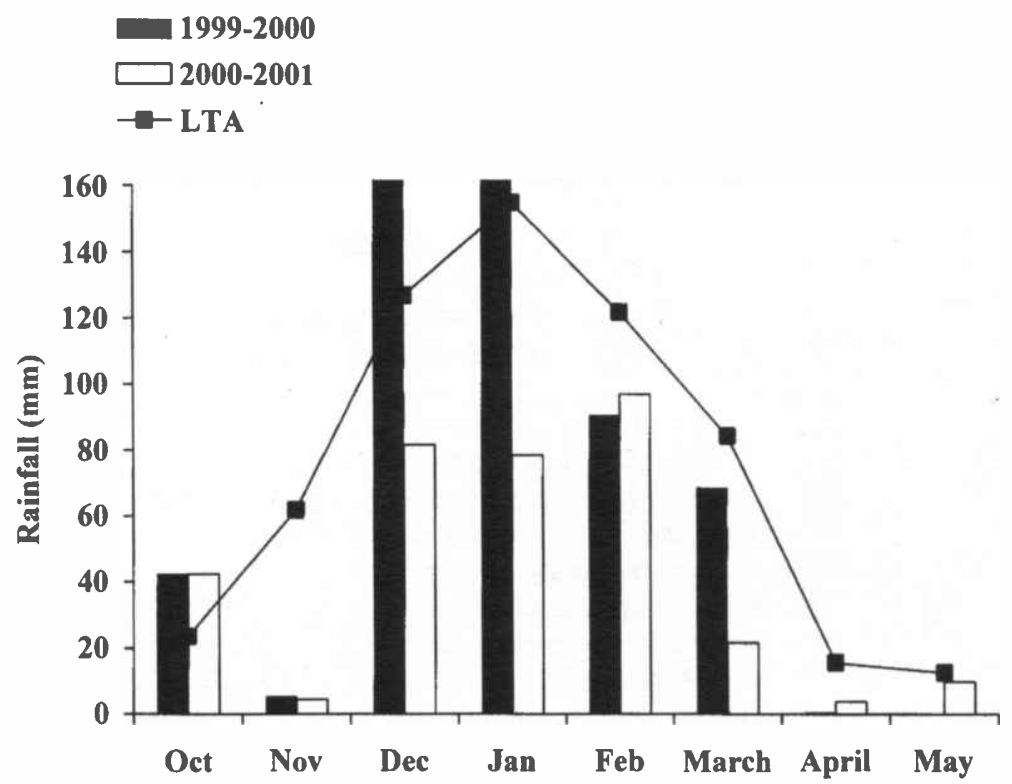

Fig. 1. Rainfall distribution for 1999-2000 and 2000-2001 growing seasons and long-term precipitation average for 1990-2001 (LTA) at Samta.

During the 2000-2001 growing season, crude protein $(\mathrm{N} \times 6.25)$ and crude fiber were determined according to the AOAC (1984) procedures. Each sample was analyzed twice and the average was recorded.

\section{Statistical Analyses}

Growth and morphological data were analyzed as a 1 factor randomized complete block design and 4 replicates. The factor is the combination of the 2 seasons and the defoliation date (28 February, 15 March, 30 March, 15 April, and plant maturity). Crude protein and crude fiber were analyzed as a randomized complete block design. The experimental data were statistically analyzed and the means were separated using Fisher's Least Significant Difference (LSD) (Steel and Torrie 1980).

Results and Discussion

Variation in total rainfall and distribution was high between the two seasons. In 1999-2000 more than 50\% of the rainfall occurred during December and January, whereas April was a dry month (Fig. 1) similar to the long-term average. Precipitation for 2000-2001 was only 50\% of the long-term average $(339 \mathrm{~mm})$, but because of a wet April and May, dual-purpose barley grew normally.

The crude protein contents of dual-purpose barley declined during the season. The highest protein contents $(P \leq 0.05)$ were $25 \%$ on 28 February $2000-2001$ and declined to the lowest values $(2.5 \%)$ at maturity (Fig. 2). Although protein often limits range livestock production, protein supplementation is cost effective, due to improved forage intake and digestibility (Holechek and Herbel 1986). Even sheep fed whole matured dual-purpose barley required protein supplementation. Buxton and Marten (1989) found that the crude protein content of several grass species was closely related to calendar days. Barley herbage at the tillering stage has a protein content equivalent to that of forage legumes (Droushiotis and Wilman 1987). Erickson et al. (1982) reported a $20 \%$ crude protein content in green barley tissues. The results of this study indicated that dual-purpose barley has a high protein content during the active growth period, which was also characterized by low temperatures and moist conditions. Protein contents ranged from 18 to $25 \%$ between 28 February and 30 March, and dropped $5 \%$ when the plant reached maturity in May 2000-2001 (Fig. 2). In contrast to protein content, fiber content was low at the February and March harvests (Fig. 2). However, the fiber increased gradually and peaked $(60.8 \%)$ when the plant 
reached maturity. Henderson and Robinson (1982a, 1982b) also reported that high temperature and low soil moisture stresses reduce the nutritive value of the plant regardless of the tissue.

Plants were taller in 1999-2000 compared to 2000-2001. Clipping the plants on 28 February ( 48.5 and $29.8 \mathrm{~cm}$, respective years) and 15 March (35.0 and 32.5 $\mathrm{cm})$ resulted in shorter plants $(\mathrm{P} \leq 0.05)$ than unclipped plants $(89.6$ and $39.1 \mathrm{~cm}$, respectively). Plants defoliated 30 March and 15 April did not regrow (Fig. 3). ElShatnawi et al. (1999) found that clipping wall barley (Hordeum murinum L.) plants during early tillering stage did not affect plant height when measured at physiological maturity. However, the ultimate plant height was reduced when clipping at the jointing and booting stages. Highest reduction in the final plant height occurred when clipping at booting. The high demand of photosynthetic products during the reproductive stage coincided with low photosynthetic efficiency due to hot and dry conditions and this may be responsible for regrowth inhibition.

The number of tillers produced by unclipped plants during 1999-2000 and 2000-2001 (3.8) were the same as the number of tillers produced by plants that were clipped on 28 February (4.0 and 3.5, respectively) and 15 March (3.3 and 4.3, respectively) (Fig. 4). Forage removal usually modifies plant tillering (Sharrow and Motazedian 1987). A reduction in the number of reproductive tillers due to spring grazing treatments is common (Aase and Siddoway 1975, Dunphy et al. 1982). However, higher number of tillers in defoliated compared to undefoliated grass plants has also been reported (Sharrow and Motazedian 1987, ElShatnawi and Ghosheh 1998). Clipping dual-purpose barley after mid March inhibited tiller production. Similarly, tiller production was only inhibited when wall barley plants were defoliated at the reproductive stage (El-Shatnawi and Gosheh 1998).

The seed yields of unclipped dual-purpose barley plants were 3.8 and $2.8 \mathrm{~g}$ per plant for 1999-2000 and 2000-2001, respectively (Fig. 5). Similar seed yields were recorded for unclipped plants and those clipped 28 February. There was no seed production when plants were clipped 30 March and 15 April (reproductive stage). Late clipping injured plants under Mediterranean conditions, because of the rapid reduction in soil moisture and the increase in air temperature in late spring that ended the growing season. Defoliation
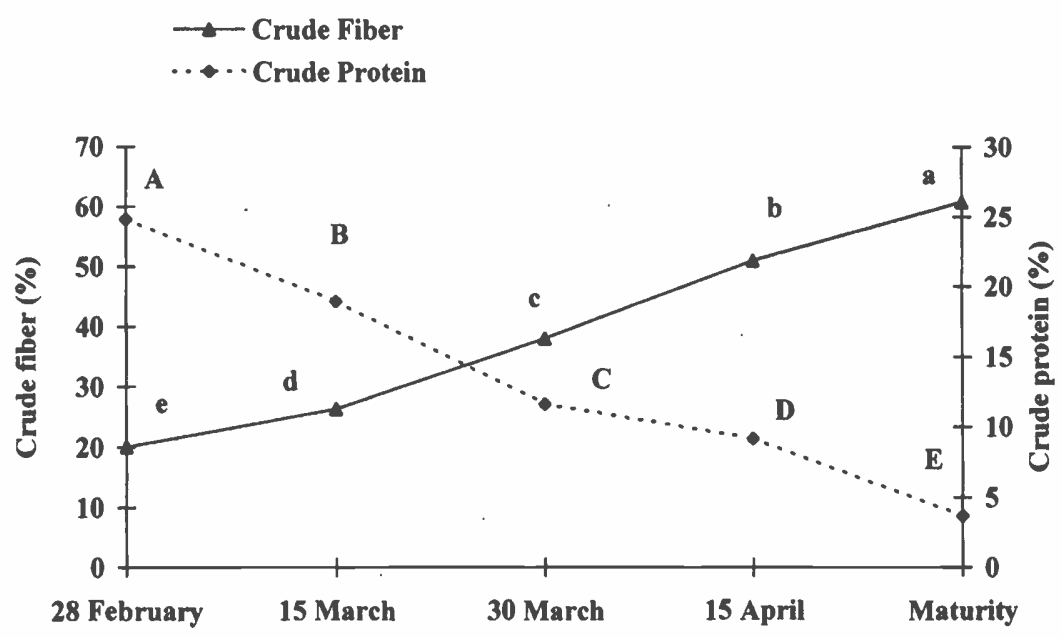

Fig. 2. Changes in crude protein and fiber contents of $\boldsymbol{H}$. spontaneum during 2000-2001 at Samta. Means with different letters differ significantly according to Fisher's Least Significant Difference at $\mathbf{P} \leq \mathbf{0 . 0 5}$.

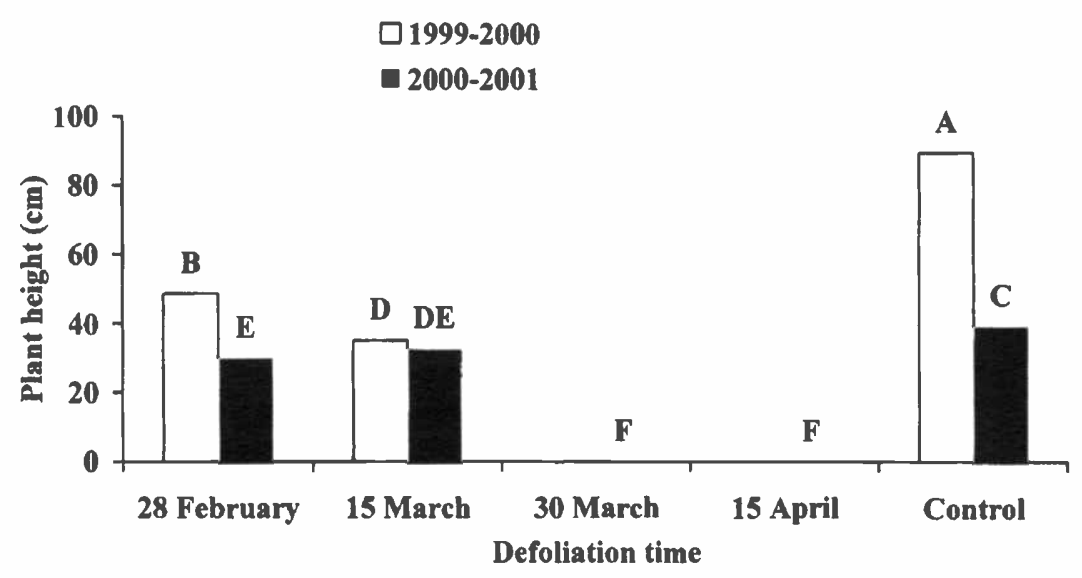

Fig. 3. Effect of defoliation time on plant height of $\boldsymbol{H}$. spontaneum $\mathbf{L}$. Columns with different letters differ significantly according to Fisher's Least Significant Difference at $\mathbf{P} \leq \mathbf{0 . 0 5}$.

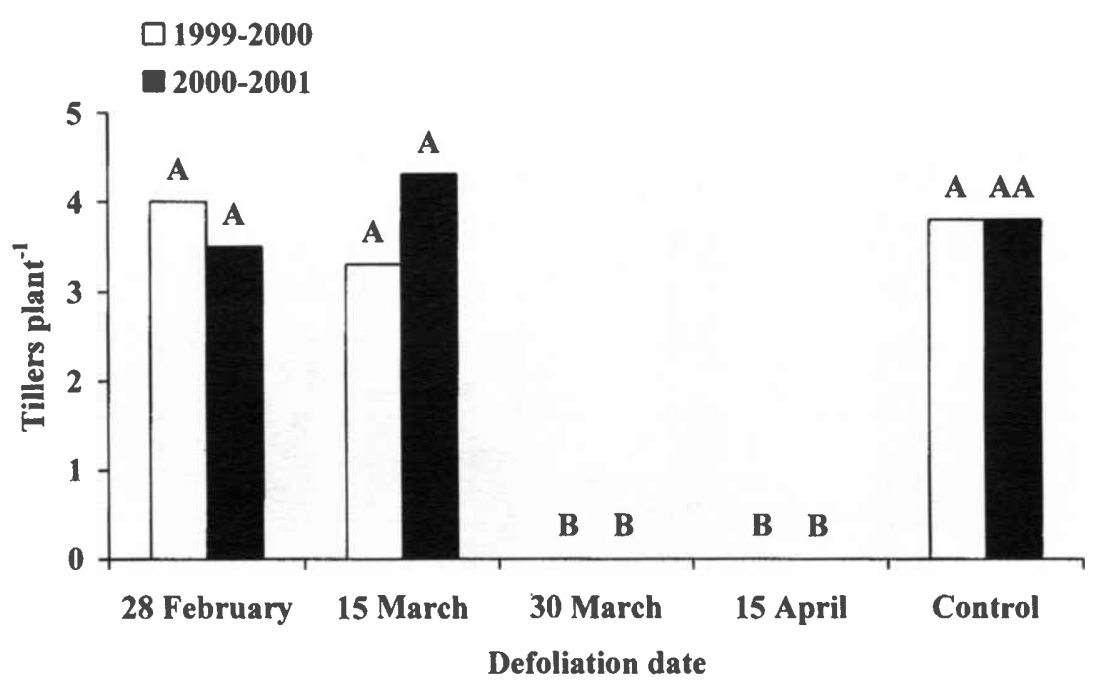

Fig. 4. Effect of defoliation time on number of tillers per plant of $\boldsymbol{H}$. spontaneum $\mathbf{L}$. Columns with different letters differ significantly according to Fisher's Least Significant Difference at $\mathbf{P} \leq \mathbf{0 . 0 5}$. 


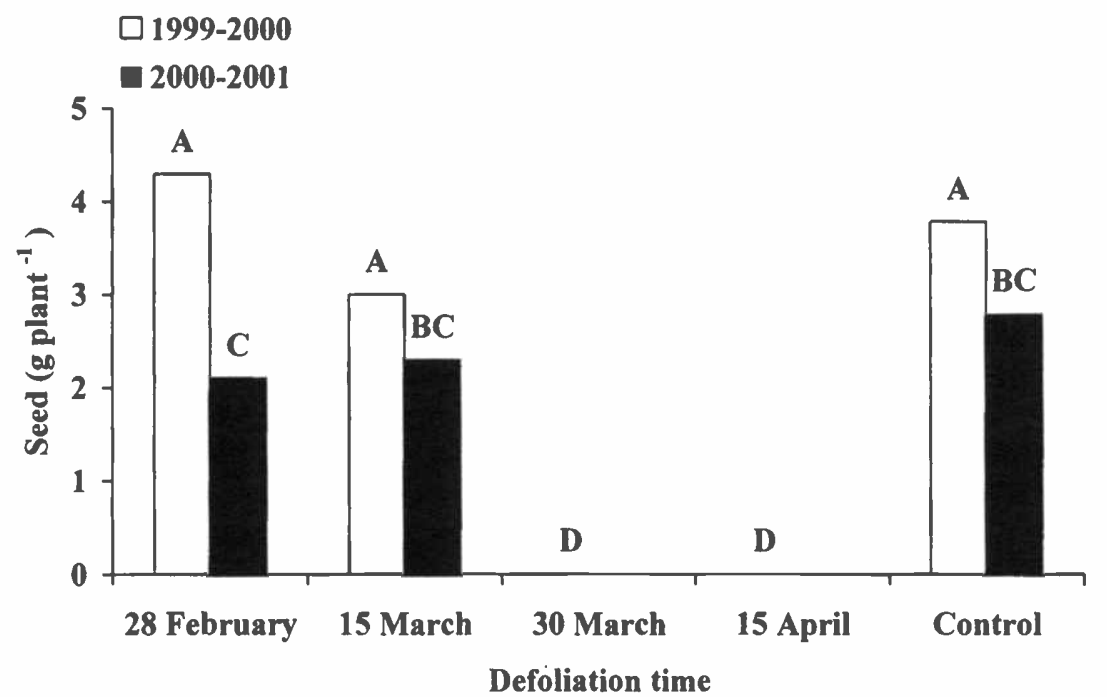

Fig. 5. Effect of defoliation time on seed $\left(\mathrm{g} \mathrm{plant}^{-1}\right)$ of $\boldsymbol{H}$. spontaneum $\mathrm{L}$. Columns with different letters differ significantly according to Fisher's Least Significant Difference at $P \leq 0.05$.

appears to be particularly detrimental during periods of limited water availability (Larcher 1995).

Clipping at the reproductive stage may inhibit seed production. Inhibiting seed production might eliminate dual-purpose barley from a site because it depends on a soil seed bank for its stability and persistence. Seed production was not adversely affected when clipping occurred at tillering, regardless of clipping height (ElShatnawi and Gosheh 1998, El-Shatnawi et al. 1999), indicating that seed reserve will not be depleted if defoliation occurred early in the growing season. Mowing grasses in early spring did not affect seed head production, whereas, late spring mowing reduced seed head density of grass species (Sims et al. 1971).

Shoot weights of individuals clipped on 28 February (14.3 and $9.6 \mathrm{~g} \mathrm{plant}^{-1}$, respective years) and 15 March (10.3 and $9.2 \mathrm{~g} \mathrm{plant}^{-1}$, respective years) were the same as for unclipped control plants (Fig. 6). The lowest $(P \leq 0.05)$ shoot weights were obtained from plants clipped 30 March (5

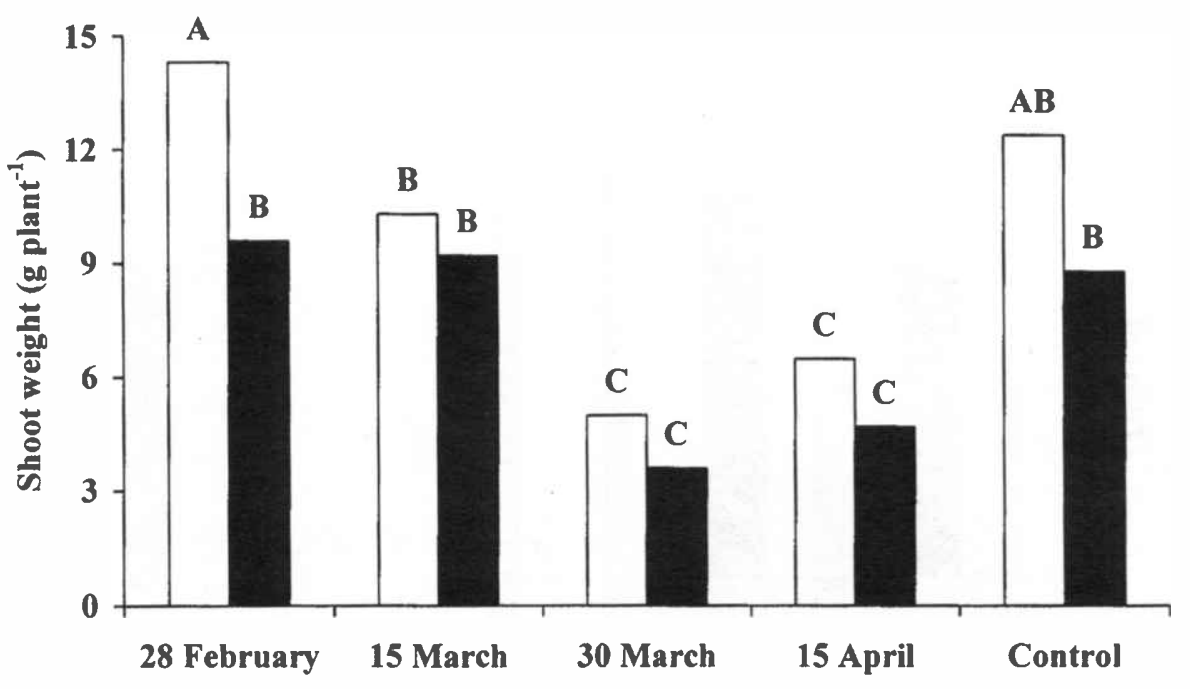

Defoliation time and $3.6 \mathrm{~g} \mathrm{plant}^{-1}$, respective years). Forage production from the first cut increased with delayed defoliation time (Fig. 7). The first cut on 15 April, 1999-2000 and 2000-2001 (1554 and $994 \mathrm{~kg} \mathrm{ha}^{-1}$, respectively) produced higher amounts of forage than the first cut on 28 February (261 and $194 \mathrm{~kg}$ ha $^{-1}$, respectively), 15 March (446 and 298 $\mathrm{kg} \mathrm{ha}^{-1}$, respectively) and 30 March (874 and $593 \mathrm{~kg} \mathrm{ha}^{-1}$, respectively). Oven-dry forage weights of the dual-purpose barley plants that were clipped 28 February (2902 and $1274 \mathrm{~kg} \mathrm{ha}^{-1}$ ) were the same as the weights of the unclipped plants (2826 and $\left.1089 \mathrm{~kg} \mathrm{ha}^{-1}\right)$. The lowest $(\mathrm{P} \leq 0.05)$ amount of dry shoot weights (Fig. 8) was obtained from the plants clipped 30 March (874 and $\left.593 \mathrm{~kg} \mathrm{ha}^{-1}\right)$.

El-Shatnawi et al. (1999) reported that the highest forage yield was obtained when wall barley plants were clipped at tillering stage. This indicates that clipping at the tillering, did not impede regrowth of wall barley under semi-arid conditions. Previous observations indicated that plant responses to defoliation were highly variable with time of defoliation (Miller and Donart 1979). The most critical defoliation time was either during the reproductive stages or under unsuitable environmental conditions (Mullahey et al. 1990). Results from this study agree with those for plants defoliated in 30 March and 15 April (Fig. 8).

Clipping at the reproductive stage coincided with high temperature and low precipitation at the end of the rainy season. Maximum plant sensitivity to grazing also appeared to coincide with reproduction and/or declining soil water availability. Daytime temperature (Frank et al. 1992), moisture supply (Thakur and Shands 1954), and proper grazing management (Morey 1961) contribute to high forage and seed yields of small grain crops under simulated grazing. High temperatures cause reversible alterations in the physicochemical state of biomembranes and the conformation of protein molecules. Photosystem II is inhibited, photosynthesis is subsequently depressed, and eventually this results in death of the cells (Bjorkman et al. 1972). In the presence of an additional stress (e.g. water stress), there are already signs of incipient inhibition of photosynthesis from $30^{\circ} \mathrm{C}$ upwards (Larcher 1995). Dryness results from combination of low precipitation and high water evapotranspiration.

Fig. 6. Effect of defoliation time on individual shoot weight $\left(\mathrm{g} \mathrm{plant}^{-1}\right)$ of dual-purpose barley (H. spontaneum $L_{\text {.) }}$. Columns with different letters differ significantly according to Fisher's Least Significant Difference at $\mathbf{P} \leq \mathbf{0 . 0 5}$. 


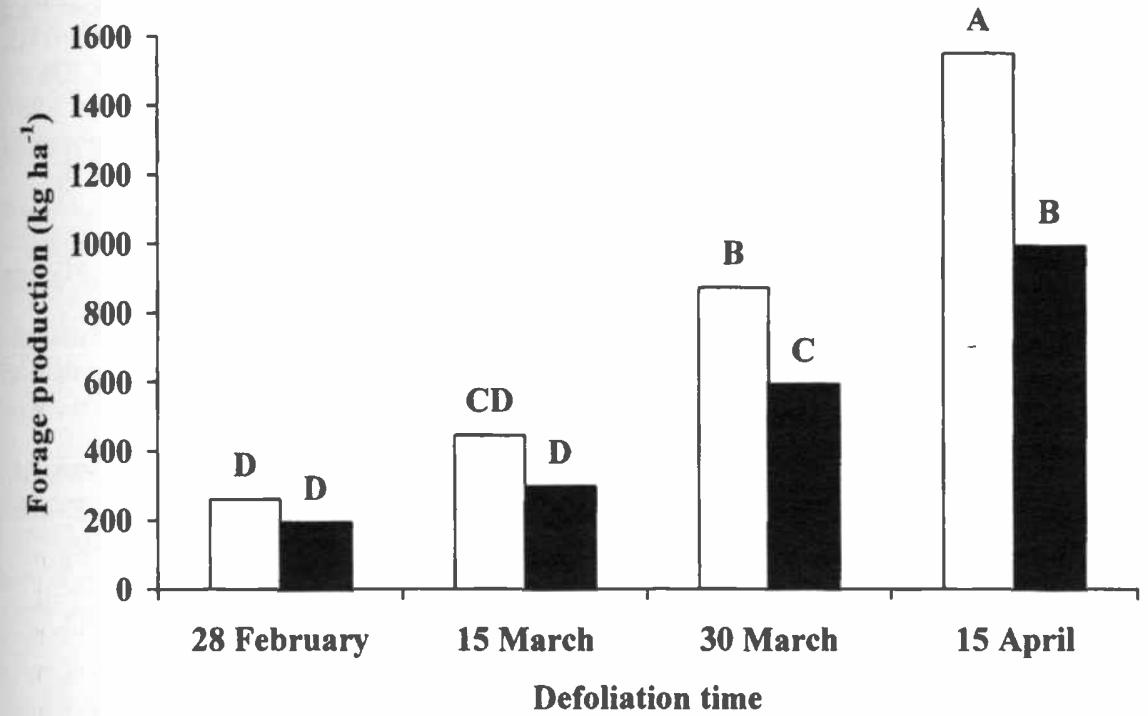

Fig. 7. Dry forage production ( $\left.\mathrm{kg} \mathrm{ha}^{-1}\right)$ of dual-purpose barley $(H$. spontaneum L.) from the first cut. Columns with different letters differ significantly according to Fisher's Least Significant Difference at $\mathbf{P} \leq \mathbf{0 . 0 5}$.

\section{Management Implications}

To minimize the problem of dual-purpose barley plant lodging under moist and fertile soil conditions, livestock would graze the crop at tillering stage without any decreases in forage and grain yield at maturity during May. However, under low

rainfall conditions, grain yield decreased $33 \%$ and straw yield decreased $40 \%$ (Hadjichrostodoulou 1983). Daytime temperature (Frank et al. 1992), moisture supply (Thakur and Shands 1954) and proper grazing management (Morey 1961) contribute to high forage and seed yields of

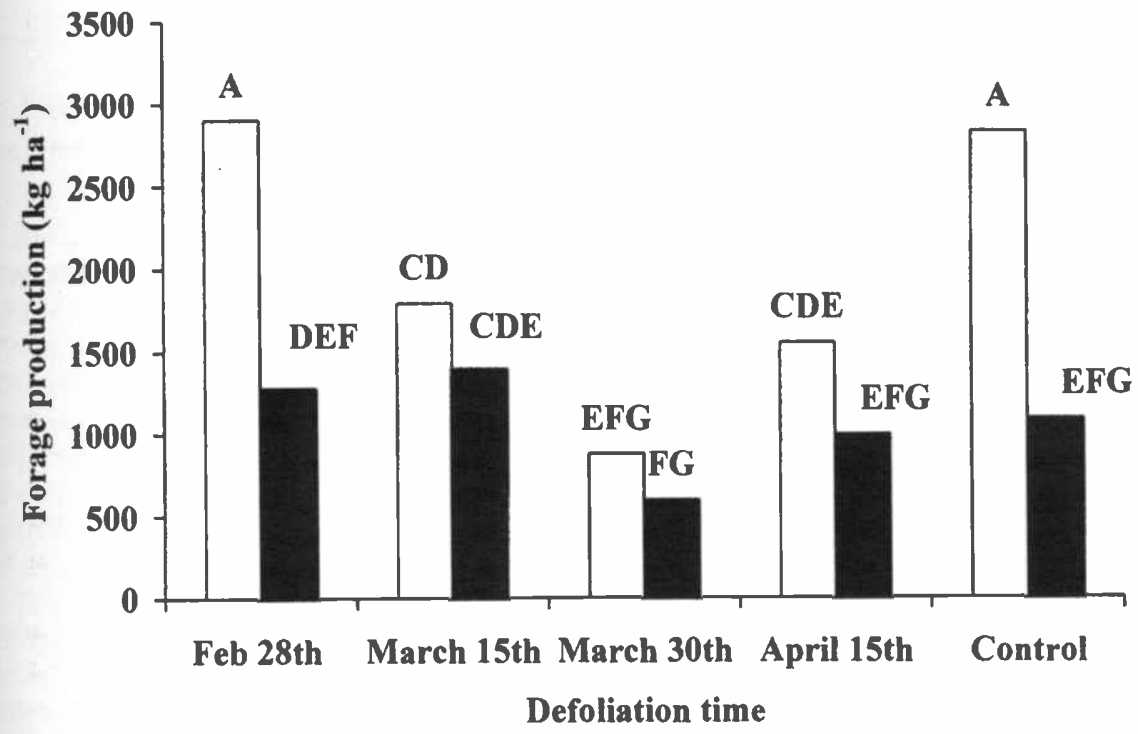

Fig. 8. Effect of defoliation time on forage production $\left(\mathrm{kg} \mathrm{ha}^{-1}\right)$ of $\boldsymbol{H}$. spontaneum $\mathrm{L}$. Columns with different letters differ significantly according to Fisher's Least Significant Difference at $\mathbf{P} \leq \mathbf{0 . 0 5}$. small grain crops under simulated grazing. High temperature and dry conditions may inhibit inflorescence initiation (Evans 1960). AL-Rawi et al. (1995) observed that late clipping reduced the yield of dual-purpose barley. Grazing barley at pre-stem elongation stage can allow recovery and equivalent grain production to that of ungrazed stands (Morey 1961). However, defoliation is detrimental due to the extensively use of nutrient reserves (Trlica and Cook 1971).

\section{Conclusions}

Defoliation during the reproductive stage (30 March to 15 April) inhibits seed production and reduces forage yield, which may threaten the population persistence and reduces the value of dual-purpose barley as a forage resource. Results showed that to optimize seed production, forage quality, and forage quantity, dualpurpose barley should be defoliated from 28 February to 15 March or at plant maturity. Dual-purpose barley shoot had high protein content when clipped from 28 February to 15 March.

\section{Literature Cited}

Aase, J.K. and F.H. Siddoway. 1975. Regrowth of spring-clipped winter wheat in the northern Great Plains of the United States. Can. J. Plant Sci. 55: 631-633.

AL-Rawi, B.A. , A.M. AL-Shamma, and J.A. Mohammed. 1995. Effect of delay of the second round clipping on the performance of some dual-purpose barley lines. In: Haddad, N., R. Tutwiler and E. Thomson (eds.), Improvement of Crop-Livestock Integration Systems in West Asia and North Africa. Savvy Press, Syria.

Anderson, W.K. 1985. Production of green feed and grain from grassed barley in northern Syria. Field Crops Res. 10:57-75.

Association of Official Analytical Chemists (AOAC). 1984. Official Methods of Analysis Washington, D.C.

Bjorkman, O., R.W. Pearcy, A.T. Herrison, and H.A. Mooney. 1972. Photosynthetic adaptation to high temperatures: a field study in Death Valley, California. Sci. 175:786-789.

Bsoul, M. 2002. Soil morphology of canopy and intercanopy sites within a broad leaved forest area. M. Sc. Thesis, Jordan Univ. Sci. Tech, Jordan.

Buxton, D.R. and G.C. Marten. 1989. Leaf and stem forage quality of big blue stem and switchgrass. Agron. J. 75:429-435.

Cherney, J.H. and G.C. Marten. 1982. Small grain crop forage potential: I. Biological and chemical determinants of quality and yield. Crop Sci. 22: 227-231. 
Droushiotis, D.N. and D. Wilman. 1987. Effects of harvesting program and sowing date on the forage yield, digestibility, nitrogen concentration, tiller and crop fractions of barley in Cyprus. J. Agr. Sci. 109:95-106.

Dunphy, D.I., M.E. McDaniel, and E.C. Holt. 1982. Effect of forage utilization on wheat grain yield. Crop Sci. 22: 106-109.

El-Shatnawi, M.K.J. and H. Ghosheh. 1998. Effect of clipping on wall barley (Hordeum murinum L.): tillering and forage production. Afri. J. Range Forage Sci. 15:92-96.

El-Shatnawi, M.K.J., H.Z. Ghosheh, H.K. Shannag, and K.I. Ereifej. 1999. Defoliation time and intensity of wall barley in the Mediterranean Rangeland. J. Range Manage. 52:258-262.

Erickson, D.O., D.W. Meyer, and A.E. Foster. 1982. The effect of genotypes on the feed value of barley straws. J. Anim. Sci. 55:1015-1025.

Evans, L.T. 1960. The influence of temperature on flowering in species of Lolium and in Poa pratensis. J. Agr. Sci. 54:410-16.

Frank, A.B., A. Bauer, and A.L Black. 1992. Effects of air temperature and fertilizers nitrogen on spike development in spring barley. Crop Sci. 32:793-797.

Hadjichristodoulou, A. 1983. Dual Purpose Barley. Agriculture Research InstitueMinistry of Agriculture and Natural Resources (Nicosia, Cyprus), Tech. Bull., p. 46.

Henderson, M.S. and D.L. Robinson. 1982b. Environmental influences on yield and in vitro true digestibility of warm- season perennial grasses and the relationship to fiber components. Agron. J. 74:943-946.
Henderson, M.S. and D.L. Robinson. 1982a. Environmental influences on fiber component concentration of warm- season perennial grasses. Agron. J. 74:573-579.

Holechek, J.L. and C.H. Herbel. 1986. Supplementing range livestock. Rangelands 8:29-33

Jameson, D.A. and D.L. Huss. 1959. The effect of clipping leaves and stems on number of tiller, herbage weights, root weights, and food reserves of little bluestem. J. Range Manage. 12:122-126.

Kalmbacher, R.S., F.G. Martin, and J.M.S. Andrade. 1981a. Mineral content in creeping bluestem as affected by time of cutting. J. Range Manage. 34:406-408.

Kalmbacher, R.S., F.G. Martin, and J.M.S. Andrade. 1981b. Yield and quality of creeping bluestem as affected by time of cutting. J. Range Manage. 34:471-474.

Kroth, E., R. Mattas, L. Meinke, and A. Matches. 1977. Maximizing production potential of tall fescue. Agron. J. 69:319-322.

Larcher, W. 1995. Physiological plant ecology. Springer, Berlin, Germany.

Louis, S.L., A. Dankintafo, B. Bookary, and N. Goumey. 1983. Seasonal influence on the nutritive value of the rangeland in Niger pastoral zone. Ministry of Rural Development US AID Tech. Bull. 2. Tahoua, Niger.

Miller, R.F. and G.B. Donart. 1979. Response of Bouteloua eripoda (Torr.) Torr. and Sporobolus flexuosus (Thurb.) Rydb. to season of defoliation. J. Range Manage 38:21-26.

Morey, D.D. 1961. Forage production of small grain under maximum favorable conditions. Agron. J. 53:57-59.
Moser, L.E. and L.J. Perry. 1983. Yield, vigor and persistence of sand lovegrass (Eragrosits trichodes) following clipping treatments. J. Range Manage. 36:236-238.

Mullahey, J.J., S.S. Waeler, and L.E. Moser. 1990. Defoliation effects on production and morphological development of little bluestem. J. Range Manage. 36:236-238.

Sharrow, S.H. and I. Motazedian. 1987. Spring grazing effects on components of winter wheat yield. Agron. J. 79:502-504.

Sims, P.L., L.J. Ayuko, and D.N. Hyder. 1971. Developmental, morphology of switchgrass and sideoats grama. J. Range Manage. 24:357-360.

Steel, R.G.D. and J.H Torrie. 1980. Principles and Procedures of Statistics:A ,Biometrical Approach. $2^{\text {nd }}$ ed. McGraw-Hill Co., New York, N.Y.

Stidham, N.D., J. Powell, F. Gary, and P.L. Claypool. 1982. Establishment, growth, utilization and chemical composition of introduced shrubs on Oklahoma Tallgrass Prairie. J. Range Manage. 35:301-304.

Tarassoum, T. 1982. Some effects of clipping on the developmental morphology of mesa drop seed. M. S. Thesis. New Mexico State Univ., Las Cruces, N.M.

Thakur, C. and H.L. Shands. 1954. Spring small grain agronomic response to plant clipping when seeded at two rates and fertilized at two levels of nitrogen. Agron. J. 46:15-16

Trlica, M.J. and C.W. Cook. 1971. Defoliation effects on carbohydrate reserve of desert species. J. Range Manage. $24: 418-425$. 